\title{
„Radim sve što treba.” Aktivisti u mjesnim zajednicama u Jugoslaviji 1970-ih i 1980-ih*
}

\author{
IGOR DUDA \\ Filozofski fakultet u Puli, Odsjek za povijest \\ Pula, Hrvatska \\ igor.duda@unipu.hr
}

Uvođenje mjesnih zajednica kao samoupravnih jedinica unutar općine bilo je oblik jačanja društvenoga samoupravljanja i socijalističke izravne demokracije u Jugoslaviji te, prema marksističkoj teoriji, dio procesa odumiranja države. Začetke donosi Ustav iz 1963., no tek Ustavom iz 1974. mjesne su zajednice postale obavezan oblik samoupravnoga organiziranja građana. Zamišljene kao svojevrsne proširene obitelji, umnogome su ovisile o inicijativi odozdo i djelovanju aktivista. Rad donosi teorijske pretpostavke i praktične aspekte aktivističkoga djelovanja u mjesnim zajednicama u raznim dijelovima Jugoslavije, a na temelju analize uspostavljaju se karakteristični tipovi aktivista koji su određeni generacijskim, klasnim i interesnim odnosima. Podaci se ponajviše crpe iz onodobne literature, specijaliziranoga lista Mjesna zajednica i arhivskoga gradiva.

Ključne riječi: mjesna zajednica; društveno samoupravljanje; socijalistička demokracija; participacija; aktivizam; Jugoslavija

U tisućama mjesnih zajednica, u tim osnovnim jedinicama jugoslavenskoga socijalističkog društva, sedamdesetih i osamdesetih godina uspostavljala se socijalistička izravna demokracija. Ideja o okupljanju širega susjedstva i kapilarnom širenju društvenoga samoupravljanja među građanima po gradskim četvrtima i selima davala je rezultate. Primjerice, u vukovarskoj Mjesnoj zajednici Borovo naselje zajednički su djelovali „profesori, suci, pravnici, grafičari, visokokvalificirani radnici i drugi aktivisti različitih zvanja i zanimanja”. ${ }^{1}$

\footnotetext{
Ovaj je rad financirala Hrvatska zaklada za znanost projektom HRZZ IP-01-2018-5394 (Mikrostrukture jugoslavenskoga socijalizma: Hrvatska 1970-1990).

1 „Najmlađa, a najbolja!”, Mjesna zajednica (dalje: MZ) (Beograd; Zagreb), br. 2, 1985., 21.
} 
U također nagrađivanoj Mjesnoj zajednici Grčica u Općini Brčko isticali su ulaganje novca i fizičkoga rada u infrastrukturu, no nešto drugo bilo im je važnije: „To su brojni aktivisti što neprekidno bdiju nad svim akcijama. To su rezultati u razvoju socijalističkih samoupravnih odnosa, komisijskom radu, razvoju kulture, sporta i fizičke kulture među mladima..." U svim dijelovima Jugoslavije mnogi građani ulagali su svoj entuzijazam, radnu energiju i slobodno vrijeme sa željom da doprinesu kvaliteti života u svojem neposrednom susjedstvu. Oni članovi društva koji su bili najviše angažirani „oko pitanja društveno-političkog karaktera”, neovisno o tome jesu li pripadali „rukovodstvu jedne ili više političkih organizacija”, nazivani su upravo aktivistima. ${ }^{3}$

Upravni okvir za njihovo djelovanje na lokalnoj razini od šezdesetih godina postupno postaju mjesne zajednice i to ostaju sve do raspada jugoslavenske federacije. Upravo je mjesnim zajednicama njihov tvorac Edvard Kardelj pridavao važnost jednaku revolucionarnoj težini radničkih savjeta. ${ }^{4}$ Držeći pojedinca odgovornim za vlastitu sreću, zaključio je da nju ne donosi „ni država, ni sistem, ni politička stranka”, nego se do nje dolazi samoupravljanjem, u ravnopravnim odnosima s drugima, uz slobodu u izražavanju i stvaranju te uz društveno vlasništvo nad sredstvima za proizvodnju. ${ }^{5}$ Robert Kramer isticao je s dužnosti sekretara Savezne konferencije Mjesna zajednica i porodica da savjet mjesne zajednice mora imati funkciju radničkoga savjeta prilagođenu mjestu stanovanja. ${ }^{6}$ Za Jurja Hrženjaka, jednoga od ključnih aktera u jačanju društvenoga samoupravljanja u raznim tijelima Socijalističkoga saveza radnog naroda (SSRN), ključ mjesnih zajednica bio je u neposrednom odlučivanju na kojem se temelji društvena, a ne državna vlast, te u „svijesti svih ili većine o vlastitom i širem društvenom interesu". ${ }^{7}$ U svojoj disertaciji, nastaloj pod mentorstvom Dušana Bilandžića i potom objavljenoj, Zdravko Tomac sedamdesetih je godina u mjesnim zajednicama vidio prostor uključivanja građana, zajedništva i solidarnosti, u čemu je trebalo sudjelovati što više građana da bi se ostvario Lenjinov ideal: „U socijalizmu svi će upravljati po redu i brzo će se naviknuti da nitko ne upravlja."8

Međutim, praksa je mogla odudarati od ideala. Kako je zapravo bio zamišljen koncept mjesnih zajednica? Je li interes građana dosezao očekivanu razinu i tko su među njima bili aktivisti? Što je poticalo njihov entuzijazam i kako su razumijevali svoje djelovanje? Ključna su to pitanja na koja nastoji

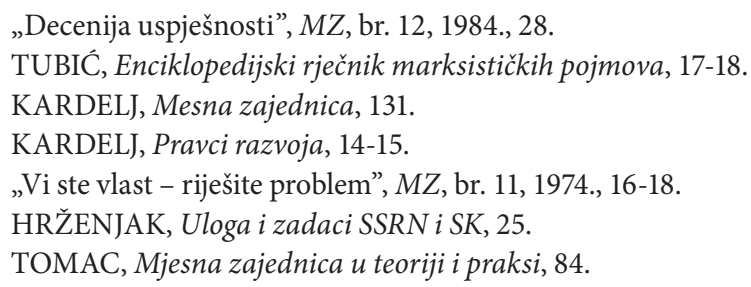


odgovoriti ovaj rad, objašnjavajući najprije upravni položaj mjesne zajednice, a potom razrađujući funkciju proširene obitelji koja joj je bila namijenjena i koja je usmjeravala potrebu za aktivnim sudjelovanjem građana. Naposljetku rad predstavlja odabrane aktiviste, njihovu motivaciju, odnos njihova radnoga i slobodnoga vremena, njihovu nezamjenjivost $u$ lokalnoj sredini te donosi njihovu tipologiju određenu generacijskim, klasnim i interesnim odnosima. Participacija i aktivizam smješteni su u prostor između makrohistorijskoga i teorijsko-pravnoga okvira te mikrohistorijskih izvedbi u raznim dijelovima Jugoslavije. Akteri tih izvedbi snalazili su se u procesu marksistički shvaćenog odumiranja države, uvođenja delegatskoga sustava i jačanja društvenoga samoupravljanja. Od 1974. djelovali su unutar samoupravnoga trokuta određenog mjesnom zajednicom (MZ) na adresi stanovanja, osnovnom organizacijom udruženog rada (OOUR) na radnome mjestu te samoupravnom interesnom zajednicom (SIZ) kao izvorom financiranja. Nisu svi aktivisti u tom trokutu bili jednako uspješni u usklađivanju susjedstva, poduzeća i fondova koji su se punili doprinosima iz osobnoga dohotka (plaća) i dohotka poduzeća te potom preko SIZ-a bili usmjeravani prema zadovoljavanju potreba građana u određenim djelatnostima, primjerice zdravstvu, obrazovanju i stanogradnji.

Spomenuti Borovo naselje i Grčica među brojnim su primjerima iz svakodnevne prakse o kojima je redovito izvještavao list Mjesna zajednica, mjesečnik novinskoga formata s redakcijama u Zagrebu i Beogradu, koji je izlazio pod okriljem Socijalističkoga saveza radnog naroda Jugoslavije (SSRNJ). Za ovaj rad posebno su korisni bili članci o aktivistima, objavljivani između 1972. i 1990., no list je općenito prvorazredni i primarni izvor za razumijevanje onodobnih predodžbi o mjesnim zajednicama na jugoslavenskoj razini, i onih odozdo kroz njihovu samoreprezentaciju, i onih odozgo preko promicanja odabranih uzora i davanja praktičnih smjernica određenih zakonskim i ustavnim okvirom. Rad se temelji i na arhivskim izvorima koji svjedoče o shvaćanju uloge aktivista i uključivanju građana u rad mjesnih zajednica. Riječ je o dokumentaciji iz fonda Republičke konferencije Socijalističkoga saveza radnog naroda Hrvatske (SSRNH), posebno njezina Koordinacionoga odbora za rad mjesnih zajednica, koja se čuva u Hrvatskom državnom arhivu. Neizostavan oslonac je literatura, ponajviše ona iz recentne upravne znanosti i ona suvremena razdoblju kojim se ovaj rad bavi. Ta su djela ujedno i povijesni izvor jer su im autori nerijetko upravo teoretičari i ideolozi društvenoga samoupravljanja te usmjerivači razvoja mjesnih zajednica. Politologija i sociologija u socijalizmu su posvećivale znatnu pozornost društvenom samoupravljanju i delegatskom sustavu, no sedamdesetih i osamdesetih godina bilo je prerano za povijesna istraživanja aktualnoga razvoja. Nažalost, ni danas ne postoji posebna studija o mjesnim zajednicama, ni o njihovoj političkoj ulozi ni o 
svakodnevnoj praksi, koja bi potvrdila zanimanje suvremene historiografije za ovu temu.

\section{Koncept mjesnih zajednica}

Put prema mjesnoj zajednici kao „školi samoupravljanja na mjestu stanovanja” i ,školi socijalističke svijesti” bio je postupan. ${ }^{9}$ Decentralizacija i deetatizacija pedesetih su godina bile u temeljima jugoslavenske društvene reforme i među ključnim temama u traženju novih rješenja za ustroj socijalističkoga društva i lokalne uprave. Ideja o samostalnijim najnižim lokalnim jedinicama koje ne bi bile podređeno tijelo vlasti, nego samoupravne teritorijalne zajednice, u zakonodavstvu je postojala od 1955 . godine. ${ }^{10}$ Naime, ratni su narodnooslobodilački odbori 1946. prerasli u narodne odbore na svim razinama lokalne vlasti, uključujući i najnižu, gdje su djelovali narodni odbori mjesta i gradskih rajona. Razdoblje postojanja kotareva i izdvojenih gradova završilo je 1955., kad je uvedena jedinstvena podjela teritorija, odnosno komunalni sustav s općinom kao jedinom mogućom osnovnom jedinicom. ${ }^{11} \mathrm{U}$ Jugoslaviji je tada bilo 1479, a u Hrvatskoj, primjerice, 299 općina.

Tri godine poslije Savez komunista Jugoslavije (SKJ) programski se odredio prema „inicijativi masa”, „kreativnosti masa” i „stvaralačkoj aktivnosti novoga društva” kao nezamjenjivima u izgradnji „novih oblika demokracije”, „neposredne demokracije”, odnosno socijalizma u kojem ne može biti trajnoga apsolutnog monopola Partije. ${ }^{12}$ Očekivalo se tada da će vodeća uloga SKJ ubuduće nestajati praćena „objektivnim procesom odumiranja društvenih antagonizama i svih oblika prinude”, uz jačanje „obuhvatnijih oblika neposredne socijalističke demokracije”. ${ }^{13}$ Ideal „bespartijske direktne socijalističke demokracije” shvaćen je kao „oblik postepenog odumiranja pojedinih funkcija države, odnosno njihovog pretvaranja u funkcije društvenog samoupravljanja”, pri čemu „široke narodne mase” postaju „odlučujući politički činilac”. ${ }^{14}$ Važno je za SKJ tada bilo osigurati samoupravljanje „radnog naroda” u komunama, odnosno omogućiti razvoj društvenoga samoupravljanja na općinskoj razini. ${ }^{15}$ Prema Programu, sve se to moglo ostvarivati preko narodnih odbora, političkih i stručnih savjeta, zborova birača, referenduma, mjesnih odbora i

\footnotetext{
9 HRŽENJAK, Mjesna zajednica, 132; VRATUŠA, „Predgovor”, u: KARDELJ, Mesna zajednica, xii.

KOPRIĆ, „Razvitak formiranja društveno-političkih zajednica u SFRJ”, 24-25.

Isto. U skladu s tim, Koprić razlikuje politipsko i monotipsko razdoblje.

Program Saveza komunista Jugoslavije, 156.

Isto, 219.

Isto, 158-159.

Isto, $159-160$
} 
stambenih zajednica, čime je komuna prerastala $\mathrm{u}$ „najizrazitiju instituciju neposredne socijalističke demokracije koja ostvaruje vladavinu radnog naroda preko” - važno je bilo naglasiti - „samih radnih ljudi i za njih same”. ${ }^{16}$ Stambene zajednice tada su se činile dobrim okvirom za takav razvoj inicijative „neposredno zainteresiranih građana” ${ }^{17} \mathrm{U}$ pružanju pomoći i usluga bile su im bliže od komune i izravnije su mogle djelovati na stvaranju „društvene tehničke baze” za kućanstva, povezujući nastojanja odozgo „s akcijom i inicijativom neposredno zainteresiranih građana". ${ }^{18}$ Radilo se o skrbi o djeci i kućanstvu, socijalnoj i zdravstvenoj skrbi, upravljanju stambenim fondom i stanogradnjom, dostupnosti uslužnih djelatnosti, dakle i postupnom razvoju servisa kojima bi upravljali sami građani preko samoupravnih tijela. Tim više jer svaki je građanin općinskim statutom morao imati zajamčena „svoja prava i svoje obaveze kao i svoje mogućnosti upravljanja komunom" ${ }^{19}$ Dodatni zadatak komunista bio je vrlo praktičan: pripremiti i odgojiti građane za društveno samoupravljanje. ${ }^{20}$ Sve je to krajem pedesetih godina bilo dio konteksta izgradnje socijalističke demokracije, ali i spremnosti na određenu fleksibilnost u tom procesu te partijskoga jačanja zanimanja za kvalitetu života i svakodnevicu građana:

„Komunistička partija, odnosno Savez komunista Jugoslavije [...] polazio je od činjenice da se socijalizam ne stvara radi nekih apstraktnih ciljeva nego za živog čovjeka. On se zbog toga trudio i trudi se i danas da izgradnja socijalizma bude bliska radnom čovjeku Jugoslavije ne samo po svom sadržaju i po materijalnim prednostima koje mu daje nego i po svojim formama, po svojoj prilagođenosti načinu života i kulturi naroda." ${ }^{\text {21 }}$

Zacrtano prilagođavanje i približavanje građanima nastavilo se šezdesetih godina, kad su upravna i ustavna rješenja nastojala razriješiti „dilemu između tradicionalnog 'makrosocijalizma' i modernog 'mikrosocijalizma”. ${ }^{22} \mathrm{U}$ prilog tome išli su i teorijski uvidi o društvenom samoupravljanju koje bi moralo voditi k uključivanju „što većeg broja 'svih”, a taj „ljudski i grupni pluralizam” pridonosio bi debirokratizaciji odnosa i detotalitarizaciji. ${ }^{23}$ Potrebnu spontanost društvu bi davali društveni mikroorganizmi jer u njima izolirani i podređeni čovjek najlakše može postati društven i slobodan:

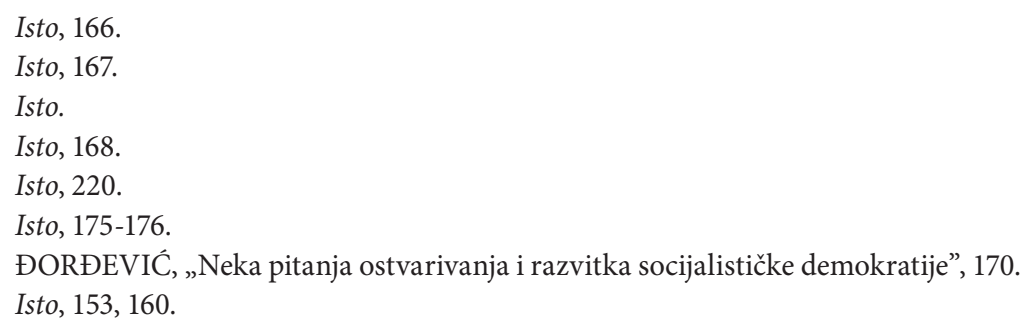


„Pojedini marksisti smatraju da su mikroorganizmi ne samo početak već i suština socijalizma, da se tu jedino može postepeno ostvarivati proces 'dezalijenacije' i 'dereifikacije’ ljudskih odnosa. Neki kuju čak i novi termin koji je čitava nova teorija socijalizma: 'mikrosocijalizam' ili čak 'mikromarksizam.'."24

U praksi je do nove upravne promjene došlo 1962. godine. U Jugoslaviji se broj općina sljedeća tri desetljeća kretao između 500 i 581, a u Hrvatskoj nije znatnije odudarao od tom reformom utvrđenih početnih 111. Općine se više nisu regionalno udruživale u kotareve, koje republike na svojem teritoriju ukidaju tijekom šezdesetih godina, a novi neobavezni stupanj ustroja na toj međurazini uveden je 1974. pod nazivom zajednice općina. Međutim, smanjivanjem broja općina šezdesetih i njihovim teritorijalnim rastom, općina se približavala nekadašnjem kotaru i udaljavala od građana te se pristupilo drugačijem organiziranju udruživanja na najnižoj razini. Iako su spomenuti mjesni odbori već imali ulogu prvoga kontakta s općinskim vlastima, ipak se 1959. počelo osnivati stambene zajednice kao oblik samouprave, poglavito u urbanim naseljima. U njihovu djelokrugu bili su komunalni, gospodarski, socijalni, zdravstveni, kulturno-prosvjetni i drugi poslovi, njihove savjete birali su građani na zborovima birača, a usprkos širokom opsegu djelovanja, zapravo su imale „naglašen neobavezan karakter” i, držeći se propisanoga okvira, radile „što hoće i što mogu”. ${ }^{25}$ Dvojstvo stambenih zajednica i mjesnih odbora održalo se nekoliko godina, do novoga ustavnog rješenja kojim su kao novina uvedene mjesne zajednice (srp. месна заједница, slov. krajevna skupnost, mak. месна заедница):

„Ustav iz 1963. spaja institut mjesnih odbora i institut stambenih zajednica u jedinstveni institut mjesne zajednice, čime započinje monotipski razvoj najnižih jedinica. Ustav određuje mjesnu zajednicu kao samoupravnu zajednicu građana koja se osniva 'za pojedina mjesta, sela i druga naselja ili za dijelove grada na području općine’ (čl. 147. st. 3. Ustava SRH 1963).”26

Kako mjesne zajednice tada nisu bile obavezne, njihovo osnivanje teklo je sporo i uz zapreke, no taj se proces još uvijek nije željelo ubrzavati posebnim zakonom, među ostalim i da se ne bi pasivizirala samoupravna inicijativa. ${ }^{27}$ Nedovoljno definirana koncepcija - samoupravna zajednica bez pravih tijela vlasti, podređena općini kao uglavnom etatističkoj tvorevini - usporavala je njihovu afirmaciju. ${ }^{28}$ Povrh toga, zbog ukidanja malih općina mjesne zajednice često su se osnivale u njihovim bivšim sjedištima i tako ipak ostajale prevelike

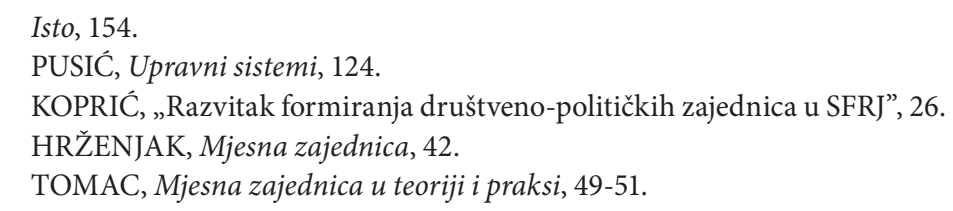


i udaljene od manjih mjesta i dijela stanovništva. Broj novih mjesnih zajednica rastao je od 3627, koliko ih je bilo 1965., do trostruko više ili 11606 jedinica 1974. godine, koja će se pokazati prijelomnom. ${ }^{29}$ Brojke su nastavile rasti, pa 1982. u 527 jugoslavenskih općina postoje 13724 mjesne zajednice; prosječno je to bilo 26 mjesnih zajednica po općini i 1618 stanovnika po zajednici. ${ }^{30}$

U međuvremenu se dogodila važna promjena donošenjem Ustava 1974., kad su mjesne zajednice postale jedan od temeljnih oblika društveno-političkoga sustava i „obvezan oblik samoupravnog organiziranja radnih ljudi i građana”. ${ }^{31}$ U tumačenjima takva sustava rado se isticalo da jugoslavenski koncept nije imao uzora i da se mogao pozvati samo na kratkotrajnu Parišku komunu i marksističku teoriju. ${ }^{32}$ Naglašavalo se da se mjesna zajednica „razlikuje od svih drugih tipova lokalne samouprave” jer je ona „lokalna zajednica”, a ne „lokalna jedinica” koja bi bila izvršitelj državne vlasti. ${ }^{33}$ Mjesna je zajednica tako pokazivala „konkretne oblike ostvarivanja marksističkog načela o odumiranju države”. ${ }^{34}$ Prema saveznom Ustavu, bilo je upravo „pravo i dužnost” građana organizirati se u mjesnu zajednicu „u naselju, dijelu naselja ili u više povezanih naselja" radi ostvarivanja zajedničkih interesa i potreba. ${ }^{35}$ Nadalje, način osnivanja utvrđivao se općinskim statutom, a načela su se pobliže mogla odrediti zakonom. Bilo je također predviđeno da se odnosi unutar mjesne zajednice kao pravne osobe utvrđuju njezinim statutom. Praksa je pokazala da su osnivači bili općinska skupština ili sami građani koji su o tome odlučivali na zboru ili referendumom. ${ }^{36}$ Redoviti izvori financiranja mjesne zajednice bila su sredstva dobivena od građana, doprinosi OOUR-a i SIZ-ova, naknade za usluge i drugi prihodi te porezi i pristojbe koje je prepuštala općina. ${ }^{37}$ Općina je bila dužna osigurati i financiranje za poslove koje bi eventualno prenijela na mjesnu zajednicu, čiji je djelokrug ionako bio vrlo širok, a da bi sve predviđeno uspješno ostvarile, mjesne zajednice samoupravnim su se sporazumima povezivale s OUR-ima i SIZ-ovima te drugim samoupravnim organizacijama i zajednicama.

„U mjesnoj zajednici radni ljudi i građani odlučuju o ostvarivanju svojih zajedničkih interesa i o solidarnom zadovoljavanju zajedničkih potreba u oblastima uređivanja naselja, stanovanja, komunalnih djelatnosti, dječje i socijalne

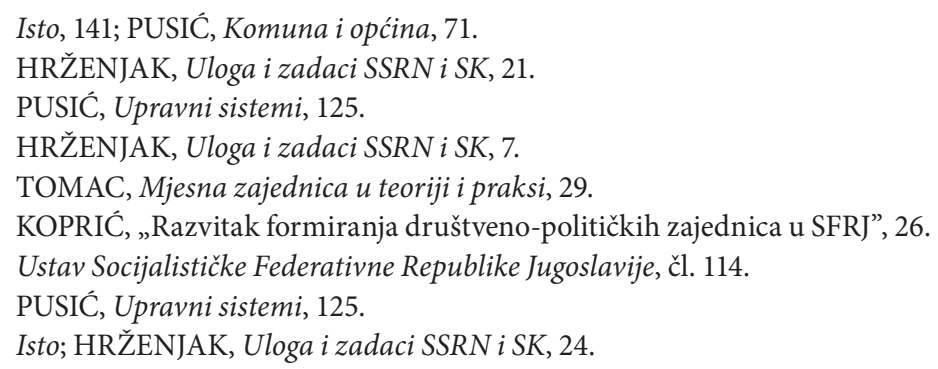


zaštite, obrazovanja, kulture, fizičke kulture, zaštite potrošača, zaštite i unapređivanja čovjekove okoline, narodne obrane, društvene samozaštite, te $u$ drugim oblastima života i rada." ${ }^{\text {38 }}$

Međutim, pokazalo se da je za uspješnije obavljanje svih zadataka potrebno potpunije definirati pravni status mjesne zajednice i postaviti ju u ravnopravan položaj s drugim organizacijama i zajednicama. ${ }^{39}$ Ta je potreba posebno rasla nakon donošenja Zakona o udruženom radu 1976. godine. Pravni pomak učinjen je republičkim zakonima o mjesnim zajednicama u prvoj polovini osamdesetih, no tek „nakon duge i uporne političke borbe” koja se odvijala istodobno sa stanjem u kojem se „dobrovoljni društveno-politički rad, ta aktivnost tisuća entuzijasta nije cijenila”. ${ }^{40}$ Svi oni sudjelovali su u tijelima mjesne zajednice: skupštinu su činili delegati građana te OUR-a i društvenih organizacija i udruga građana, skupština je imala predsjednika i tajnika te savjet kao svoje izvršno tijelo. ${ }^{41}$ Složenije odluke mogle su se temeljiti na neposrednom odlučivanju zborova građana i referendumu. Postojala su mirovna vijeća radi izbjegavanja sukoba, a unutar savjeta mjesne zajednice različite komisije te štab općenarodne obrane i društvene samozaštite. Mjesna zajednica mogla je imati savjet potrošača i korisnika usluga s ulogom zaštite potrošača na temelju samoupravnih sporazuma s OUR-ima na području mjesne zajednice. ${ }^{42}$ Takvim sporazumima rješavan je niz životnih pitanja bez upletanja općinskih vlasti, a mjesna je zajednica kao dio delegatskoga sustava slanjem delegata i formiranjem delegacija mogla utjecati na vijeće mjesnih zajednica (VMZ), kao jedan od domova općinske skupštine, te na SIZ-ove za razne djelatnosti. ${ }^{43}$ Odnosi između mjesne zajednice, OUR-a i SIZ-a temeljili su se na načelima samoupravnoga sporazumijevanja i društvenoga dogovaranja. Po tome je mjesna zajednica imala „dvostruku dimenziju” jer je sudionike toga trokuta funkcionalno i interesno povezivala, a istodobno je bila i teritorijalna samoupravna zajednica radnih ljudi i građana. ${ }^{44} \mathrm{Od}$ njih se očekivalo sve što im je dano kao ustavno pravo: „neposredno upravljanje, raspravljanje, biranje,

\footnotetext{
38 Ustav Socijalističke Federativne Republike Jugoslavije, čl. 114. Vidi: HRŽENJAK, Mjesna zajednica, 90; HRŽENJAK, Uloga i zadaci SSRN i SK, 23; TOMAC, Mjesna zajednica u teoriji i praksi, 109-116.

39 HRŽENJAK, „Uvod”, u: ĐURIĆ et al., Zakon o mjesnim zajednicama SR Hrvatske, 6.

40 Isto, 3. Vidi: „Zakon o mjesnim zajednicama”, Narodne novine (Zagreb), 19 (1983), 213-220.

${ }^{41}$ Struktura prema stanju u Hrvatskoj. Vidi: „Zakon o mjesnim zajednicama”, Narodne novine, 19 (1983).

${ }^{42}$ Vidi: DUDA, „Potrošači kao nositelji socijalizma”; DUDA, „Consumers as the Vehicles of Socialism”; DUDA, „Consumers and Self-Managers”.

43 TOMAC, Mjesna zajednica u teoriji i praksi, 110; PUSIĆ, Upravni sistemi, 125.

${ }_{44}$ TOMAC, „Općina kao samoupravna socijalistička zajednica”, 456-457.
} 
zaključivanje i odlučivanje." ${ }^{35} \mathrm{U}$ obavljanju nekih administrativnih poslova mogli su pomoći mjesni uredi, koji su u nekim sredinama imali ulogu dislociranih organa općinske oprave te su bili zaduženi za matične knjige, knjige državljana, biračke popise, ovjeravanje prijepisa ili izdavanje potvrda. ${ }^{46}$

U mjesnoj zajednici mogle su djelovati podružnice društveno-političkih i društvenih organizacija (SSRN, Savez komunista, Savez sindikata, Savez udruženja boraca Narodnooslobodilačkog rata /SUBNOR/, Savez socijalističke omladine, Konferencija za društvenu aktivnost žena, „Naša djeca”, Crveni križ i dr.), no to je ponajviše ovisilo o lokalnoj inicijativi. Očekivalo se svakako da aktivnost Saveza komunista i SSRN-a ne smije izostati, i te ključne društveno-političke organizacije morale su živom održavati svoju revolucionarnu ulogu jer - usprkos starim očekivanjima partijskoga programa s kraja pedesetih - nije bilo „iluzija da će samoupravni sistem automatski osigurati prevagu interesa radničke klase i radnih ljudi, i takve odnose, da svoje interese radnici u potpunosti i bez problema ostvaruju vlastitom djelatnošću, putem samoupravljanja” ${ }^{47}$ Očekivalo se da će se podružnice masovnih organizacija razvijati u „društvenu snagu, inspiratora i nosioca, podstrekača i koordinatora izgradnje našeg društva neposredne socijalističke demokracije”. ${ }^{48}$ Iz toga je proizlazila i uloga svojevrsne kontrolne točke za sve aktivnosti i aktiviste u mjesnoj zajednici: naime, čak i ako se po strani ostave svi usmeni dogovori i utjecaji, činjenica jest da je prijedlog popisa kandidata za sva tijela mjesne zajednice i članove delegacija utvrđivala upravo mjesna organizacija SSRN-a. ${ }^{49}$

Sudjelovanje u zajednici kao proširenoj obitelji

Zamišljeni sustav društvenoga samoupravljanja nije se u svojoj punini mogao ostvariti bez oblikovanja uže zajednice, dakle bez zainteresiranih i aktivnih građana koji bi lokalno i svakodnevno bili usmjereni jedni na druge te bili spremni pokazivati inicijativu i kreativnost. Sustav je u mjesnoj zajednici predvidio niz radnih tijela i podružnice više društveno-političkih i društvenih organizacija, no i dopuštao da štošta u konkretnim prilikama ostane na razini neostvarene mogućnosti ako je to bio odraz trenutačne volje ili nedovoljne samoupravljačke snage. Neovisno o uspješnosti u tom formalnom društvenom i političkom samoorganiziranju, jedan od osnovnih ciljeva bilo je zbližavanje građana i njihovo povezivanje u susjedstvu, odnosno Kardeljevim riječima:

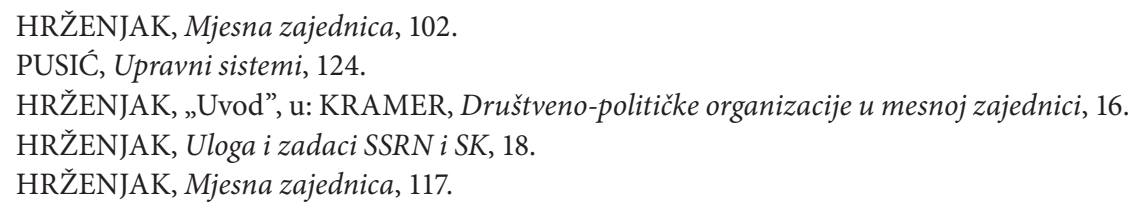


„briga o ljudima i razvijanje humanih socijalističkih odnosa” u kojima bi samoupravljači mogli djelovati kao „proširena porodica” ${ }^{50}$ Pri zamišljanju odnosa u toj široj obitelji upravo su široki odaziv i pogled odozdo bili od iznimne važnosti ,jer i najkvalitetniji stručni rad ne može u celini zameniti stvaralačko i masovno angažovanje radnih ljudi" ${ }^{51}$ Stoga su humanizacija odnosa i izbjegavanje otuđenja - uz nužnu izgradnju međusobnoga povjerenja i izbjegavanje zatvaranja u uske okvire i grupe - bili stalna tema promišljanja o mjestu pojedinca u mjesnoj zajednici. ${ }^{52} \mathrm{U}$ velikom gradu on ne bi trebao živjeti sam u „usamljenoj gomili”, nego u „realnoj socijalističkoj zajednici utemeljenoj na socijalističkom moralu i samoupravnim socijalističkim proizvodnim odnosima" ${ }^{53} \mathrm{U}$ idealno oblikovanoj sredini i uz dobre namjere, kako okruženja prema pojedincu tako i pojedinca prema okruženju, pristup je svima bio otvoren da bi građani zajedno, prema Hrženjakovim postavkama, stvarali

„[...] političke uvjete u kojima će se cijeniti i stalno potvrđivati ljudske kvalitete, radinost, poštenje, savjesnost, samoupravljačka kreativnost. Takva orijentacija i praksa socijalističke fronte ne trpi nikakvo sektašenje prema čovjeku i nikakvo dijeljenje ljudi po nacionalnosti, vjeri, školskoj spremi, položaju i radu i funkcijama, po spolu, dobi, mjestu rada, zanimanju ili po članstvu u nekoj od političkih ili društvenih organizacija ili udruženja. U frontovskoj aktivnosti mora se polaziti od cjelovitog, jedinstvenog čovjeka koji u istoj osobi predstavlja proizvođača na mjestu rada i na mjestu stanovanja, potrošača i korisnika usluga, čovjeka sa kulturnim, zdravstvenim, obrazovnim, sportskim i drugim potrebama, navikama i sklonostima". ${ }^{54}$

Dakle, radni je čovjek kao samoupravljač, proizvođač, potrošač i korisnik usluga morao moći suodlučivati o pitanjima od vlastitoga i zajedničkoga interesa te time osiguravati ekonomsku i socijalnu sigurnost. ${ }^{55}$ Međutim, prava nisu dolazila bez obveza - jer „svatko sposoban za rad mora raditi i živjeti od svog rada”, svatko „vlastitim radom prema svojim sposobnostima pridonosi zadovoljenju svojih potreba i potreba zajednice” te tada može uživati „plodove svoga rada i materijalnog napretka zajednice”. ${ }^{56}$ Poticajna klima i aktiviranje potencijala bili su stoga važan dio onodobnoga diskursa, a sve s ciljem izbjegavanja desocijalizacije i dehumanizacije, koje su, prema Hrženjakovim očekivanjima, mogle dovesti do depolitizacije, odnosno do stanja u kojem čovjek

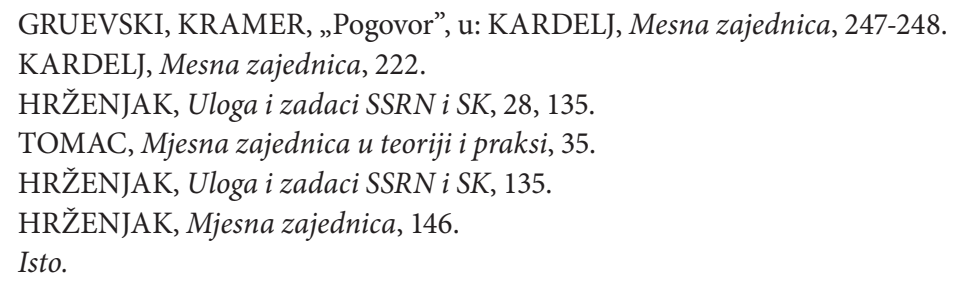


„može postati sklon svemu antidruštvenom”. ${ }^{57}$ Upravo su pasivnost i nezainteresiranost shvaćane kao osobine koje su bile ostatak građanskoga predstavničkog sustava i koje su reproducirale etatističke tendencije. ${ }^{58} \mathrm{U}$ društvu koje je gradilo odmak od staroga, opasnosti depolitizacije mogle su se izbjeći samo uključivanjem građana u konkretne poslove i akcije o kojima su odlučivala tijela mjesnih zajednica:

„Samo ako građani u svakoj mjesnoj zajednici - preko raznih odbora, komisija, sekcija, društvenih organizacija, zatim izjašnjavanjem putem anketa itd. - budu stalno u toku svih bitnih pitanja koja se pripremaju za razmatranje na zborovima radnih ljudi, tada će i njihovo odlučivanje imati svoj potpuni smisao i bit će kvalificirano." 59

Međutim, već na početku sedamdesetih godina za Kardelja je to značilo da svakome treba pružiti mogućnost za sudjelovanje, ali ne i da svatko „može, hoće ili mora" sudjelovati u svemu. ${ }^{60}$ Bilo je i drugih koji su već tada smatrali da je iluzorno očekivati da svako pitanje podjednako zanima sve građane. ${ }^{61} \mathrm{Iz}$ toga se krajem desetljeća razvila određena bojazan ili čak jasna svijest o tome da neće svi građani biti voljni sudjelovati u društvenom samoupravljanju ili svojevrsnoj socijalističkoj izravnoj demokraciji:

„Nisam siguran da će ljudi dobro primiti takav sistem da moraju u svakoj kući ili bloku držati sastanke i političke diskusije, da tamo predlažu kandidate i da moraju to da izglasaju na zborovima itd. ${ }^{\prime 62}$

Takve su misli podlogu mogle imati u teorijskim razmatranjima, ali i u egzaktnim podacima s terena, gdje je načelo dobrovoljnosti nerijetko dovodilo do nedovoljnoga zamaha u aktivnosti mjesnih zajednica. S teorijske strane, pristajanje na dobrovoljnost može se povezati s dosljednom primjenom samoupravljanja jer odluči li samoupravljač da u upravljanju ne želi sudjelovati, na njega se ne bi trebali primjenjivati mehanizmi prinude. Mogao bi to biti uzaludan posao jer "gdje su subjektivne snage nerazvijene ili gdje se ne osjećaju potrebe, ionako nema ploda". ${ }^{63}$ Zamišljeni ideal utopijski se oslanjao upravo na nove navike i oblike ponašanja u socijalističkoj zajednici koja se vodila načelima uzajamnosti i solidarnosti. U takvu kontekstu mjesna zajednica postaje primjer odumiranja države i može, očekivalo se, funkcionirati bez profesionalnoga osoblja na koje bi građani ionako teško utjecali jer bi ono bilo postavljeno

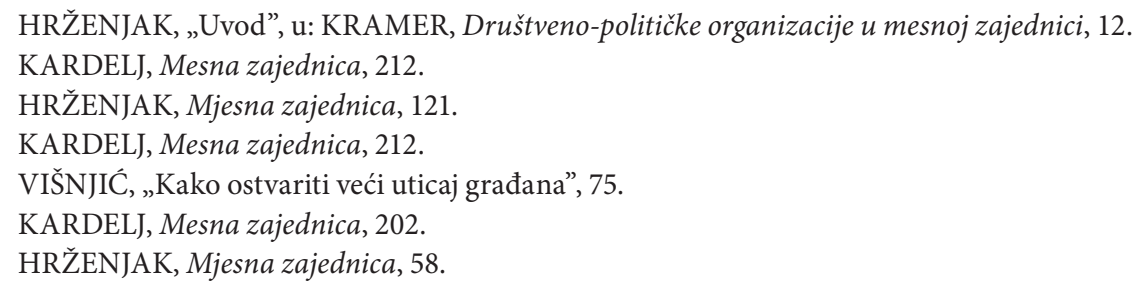


i plaćeno odozgo, od općinskih vlasti. ${ }^{64}$ Štoviše, aparat vlasti, poticaji komunista, paternalizam SSRN-a i partijsko kadroviranje nametanjem kandidata mogli su i negativno utjecati, kočiti dobre aktivnosti i inicijative odozdo te tako izravno dolaziti u sukob sa samoupravljanjem, o čemu su tada govorili i sami istaknuti komunisti. ${ }^{65}$

„U tom smislu mjesna zajednica kao samoupravna zajednica bez organa vlasti, bez mogućnosti da ostvaruje sintezu interesa prisilnim putem, bitno se razlikuje od svih sistema lokalne samouprave i u kapitalizmu i u državnom socijalizmu gdje se sinteza interesa, integracija, vrši posredništvom vlasti i političke prinude. U tom smislu mjesna zajednica znači negiranje lokalnog i centralnog; nije protivteža centralnoj vlasti nego oblik ukidanja otuđene vlasti. [...] Ovakva teorijska koncepcija mjesne zajednice bitno ju razlikuje od svih do sada poznatih tipova lokalne samouprave, čak štaviše, takva koncepcija ju i negira kao oblik lokalne samouprave."

S praktične strane to znači da sustav nije mogao funkcionirati bez, jezikom vremena rečeno, mobilizacije radnih ljudi, odnosno bez inicijative aktivnih pojedinaca koji bi animirali i motivirali veći broj građana. Među njima, zaključivalo se, „uvijek se nađe takvih koji žele raditi iz zdrave ambicije, iz zanosa, svijesti i ljubavi za neki posao, za unapređenje svog naselja, kao slobodni i svjesni građani” ${ }^{67}$ Dakle, pravi samoupravljači morali su djelovati kao entuzijasti i volonteri. Iz svega proizlazi da su idealni aktivisti u mjesnim zajednicama morali biti motivatori i mobilizatori, spremni pomoći drugome i raditi za opće dobro, biti solidarni, vrijedni i skromni, imati visoku razinu socijalne inteligencije i dovoljno slobodnoga vremena, ali i podobnu političku pozadinu ili barem onu koja ne izaziva posebne sumnje. Prvi korak u prepoznavanju takvih ljudi, njihovu motiviranju i stručnom osposobljavanju, ali i vrednovanju obavljenoga posla imale su mjesne organizacije SSRN-a, što je 1979. potvrdila i Skupština Socijalističke Federativne Republike Jugoslavije svojom Rezolucijom o daljnjem razvoju mjesnih zajednica, dodatno pozivajući na široki angažman. ${ }^{68}$ Međutim, stanje na terenu, o kojem svjedoče i arhivski izvori, bilo je šaroliko. U odboru koji se pri Republičkoj konferenciji SSRNH bavio razvojem mjesnih zajednica bili su svjesni da se u bazi odvijao rad „bezbrojnih entuzijasta [...] koji nisu štedili ni truda ni vremena”, da je bilo onih koji su izvrsno radili tako što im je „u malom notesiću u džepu zapisano sve”,

64 Isto.

65 Isto; KARDELJ, Mesna zajednica, 175; TOMŠIČ, „Borba za razvoj samoupravljanja”, 87; VIŠNJIĆ, „Kako ostvariti veći uticaj građana”, 80.

66 TOMAC, Mjesna zajednica u teoriji i praksi, 128, 130.

67 HRŽENJAK, Mjesna zajednica, 58.

68 HR-HDA-1228-SSRNH-RK, kut. 484, „Rezolucija Skupštine SFRJ o daljem razvoju mesnih zajednica, tiskano u Biblioteci mjesna zajednica”, travanj 1979. 
no složena i promjenjiva zakonska rješenja te financijsko poslovanje često nisu mogli sami svladavati, tim više što se radilo o grupi „dobrovoljnih ljudi, koji imaju niz drugih zaduženja, i sada preuzimaju na sebe tako veliku odgovornost”, pa se očekivalo da će se zato neki predsjednici mjesnih zajednica zahvaliti na povjerenoj dužnosti. ${ }^{69}$ Upozoravalo se na prevelika očekivanja prema kojima bi aktivist amater „trebao znati sve što i šef računske službe u radnoj organizaciji”. ${ }^{70}$ Morali su se znati snaći i u ozbiljnom poslu društvenoga planiranja. ${ }^{71}$ Pritom su mogli biti ostavljeni bez pomoći općinskih stručnih službi, a SIZ-ovi su ponekad reagirali samo kad bi im „aktivisti mjesne zajednice svaki dan bili na vratu" ${ }^{72}$ Pohađanje seminara bilo je od pomoći, no očekivalo se da bi ozbiljnija edukacija davala bolje rezultate i da bi tako bilo manje onih „koji su polupismeni, vuku one virmane po džepovima i svojim onim stolovima”, odnosno onih koji nakon seminara na šalteru ne znaju obaviti posao radi kojega su došli. ${ }^{73}$ Povrh toga, aktivisti su morali naučiti da se ne oslanjaju pretežno na općinski proračun, nego i na SIZ-ove i OOUR-e. ${ }^{74}$ Morali su također znati privući građane, stvoriti nove aktiviste, znajući pritom da u mjesnim zajednicama „živi čitav niz ljudi koje mi, kao aktivisti [...] ne poznajemo, mi ne znamo njihove sklonosti, njihove afinitete, mi praktički nismo znali, prema tome, njima ni prići, a prema tome, nismo ih znali ni angažirati" ${ }^{75}$ I oni su bili potrebni jer bi možda imali ona rješenja „koja mi ne možemo nikad, nas par aktivista pronaći” ${ }^{76}$

Što su o participaciji aktivista i drugih građana u sustavu socijalističke izravne demokracije govorile brojke? Godine 1982., primjerice, u skupštine i savjete mjesnih zajednica u Jugoslaviji bilo je izabrano 256212 delegata, u općinska vijeća mjesnih zajednica 13 906, a u mirovnim vijećima djelovalo je 64538 članova. ${ }^{77}$ Uzme li se u obzir broj mjesnih zajednica, po jednoj su tada po načelu izbora u neko od tijela službeno bile aktivne prosječno 24 osobe.

\footnotetext{
69 HR-HDA-1228-SSRNH-RK, D-Dokumentacija, D-3563, „Magnetofonski zapisnik sa sjednice Odbora za razvoj mjesnih zajednica RK SSRNH”, 17. 5. 1976.

70 HR-HDA-1228-SSRNH-RK, D-Dokumentacija, D-3011, „Stenografski zapisnik sa sjednice Koordinacionog odbora za aktivnost mjesnih zajednica RK SSRNH”, 18. 2. 1975.

71 HR-HDA-1228-SSRNH-RK, D-Dokumentacija, D-3563, „Društveno planiranje u mjesnoj zajednici”, 1976.

72 HR-HDA-1228-SSRNH-RK, D-Dokumentacija, D-3563, „Magnetofonski zapisnik sa sjednice Odbora za razvoj mjesnih zajednica RK SSRNH”, 17. 6. 1976.

73 Isto.

74 HR-HDA-1228-SSRNH-RK, D-Dokumentacija, D-4797, „Rezime Međurepubličkog savjetovanja na temu: Samoupravno planiranje u mjesnim zajednicama”, siječanj 1979.

75 HR-HDA-1228-SSRNH-RK, D-Dokumentacija, D-3068, „Učešće radnih ljudi i građana u MZ u odlučivanju o politici i sredstvima SIZ-ova: Magnetofonski zapisnik diskusione tribine”, 9. 6. 1975.

76 Isto.

77 HRŽENJAK, Uloga i zadaci SSRN i SK, 21.
} 
Međutim, aktivni su bili i drugi građani. Rezultati istraživanja iz sedamdesetih godina koje je za SSRNH proveo Institut za društvena istraživanja iz Zagreba iščitani su tada kao pokazatelji slaboga odaziva građana, kao znak nedovoljnoga interesa za korištenje raznih poluga društvenoga samoupravljanja, što je upozoravalo na opasnu anomaliju - na skrivanje donositelja odluka iza demokratskih formi. ${ }^{78}$ Naime, na zborovima birača $61 \%$ ispitanih sudjelovalo je rijetko ili nikako, a $39 \%$ onamo je dolazilo često. Na sastanke u mjesnoj zajednici dolazilo je $21 \%$ ispitanih, a ostali su to činili rijetko ili nikad. Kao najčešći razlog nedolaska navodio se nedostatak vremena (35\%), potom dojam da od toga nema nikakve koristi (17\%), stajalište da ženama ondje nije mjesto (12\%) ili da građani ondje nemaju što reći (9\%), a neke to jednostavno nije zanimalo (5 \%). Upitani pak o uspješnosti mjesne zajednice, čak $42 \%$ ispitanih zaključilo je da ona djeluje vrlo uspješno, 37 \% nije razmišljalo o tome, a $21 \%$ ispitanih bilo je uvjereno u loš način rada. Pritom su uočljive zanimljive regionalne razlike: u sjevernoj Hrvatskoj, Gorskom kotaru, Primorju i Istri mišljenja su bila mnogo više pozitivna nego u Slavoniji i Dalmaciji. U tom zamahu sjeverne i zapadne Hrvatske prema lokalnoj inicijativi predvodio je sjever, gdje je čak $68 \%$ ispitanih tvrdilo da su mjesne zajednice vrlo uspješne.

Svoje je istraživanje sedamdesetih godina u deset općina (Bihać, Bratunac, Goražde, Ilidža, Ilijaš, Lukavac, Maglaj, Nevesinje, Odžak, Sanski Most) provela i Komisija za standard Saveza sindikata Bosne i Hercegovine, u obzir uzevši samo zaposlene u stalnom radnom odnosu. ${ }^{79}$ Rezultati koji su tada izazvali „veliko iznenađenje” pokazali su da 10,2 \% ispitanih nije ni znalo kojoj mjesnoj zajednici pripadaju te da 59,7 \% nikad onamo nije odlazilo na sastanke, što je zapravo značilo da nisu sudjelovali u odlučivanju o potrošnji onoga dijela svojega dohotka koji su izdvojili za zajedničke potrebe. Čak 60,3 \% nije znalo koji su izvori financiranja mjesne zajednice, čak 66,6 \% nije poznavalo njezin program rada. Nadalje, čak 37,7 \% nije znalo kako njihova mjesna zajednica djeluje, 13,9 \% tim je radom bilo nezadovoljno, a 29,3 \% više ili manje zadovoljno.

Bosanskohercegovačko istraživanje prepoznalo je slabu uključenost zaposlenih u rad mjesne zajednice, no participacija građana te broj i struktura aktivista nisu bili samo tamošnji problem. U Hrvatskoj se upozoravalo na potrebu za ravnopravnom zastupljenošću u tijelima mjesne zajednice s obzirom na dobnu, spolnu, nacionalnu i socijalnu strukturu stanovništva. ${ }^{80} \mathrm{U}$ Zagrebu se

\footnotetext{
78 TOMAC, Mjesna zajednica u teoriji i praksi, 81.

79 „Što kažu radnici deset opština SR Bosne i Hercegovine o svom odlučivanju u mjesnim zajednicama”, $M Z$, br. 9, 1974., 24-25.

80 HR-HDA-1228-SSRNH-RK, D-Dokumentacija, D-3011, „Neki zadaci u vezi sa planovima i programima rada mjesnih zajednica", 1975.
} 
pozivalo na osvježavanje sastava savjeta mjesnih zajednica, koji bi morali bolje odražavati strukturu stanovništva, te na angažiranje novih ljudi i širega kruga građana. ${ }^{81}$ U zagrebačkoj Općini Trešnjevka nositelji gotovo svih aktivnosti bili su umirovljenici, radnici su zakazivali, a čak su i zaposleni članovi Saveza komunista Hrvatske smatrali da svoje partijske aktivnosti obavljaju na radnome mjestu, pa to ne moraju činiti i u mjesnoj zajednici. ${ }^{82}$ Osim za komuniste, poziv na više rada na adresi stanovanja vrijedio je i za omladinsku organizaciju, od koje se očekivalo jače animiranje mladih. ${ }^{83}$ Iz Srbije su stizale ocjene da su tisuće sposobnih ostavljene po strani i podcijenjene dok „nam 15, 20 ljudi rješava sve moguće probleme ovozemaljske”; među njima se kao predsjednik mjesne zajednice može naći i oficir ,jer je dušu dao za samoupravljanje”, iako postoje radnici koji su za to osposobljeni u svojim OUR-ima. ${ }^{84} \mathrm{Uz}$ to su vezana upozorenja o sužavanju kruga aktivista i ponavljanju uvijek istih ljudi koji su zbog svoje sveprisutnosti postali univerzalni aktivisti te time možda i odbijali one manje aktivne. ${ }^{85}$ Bio je to problem o kojem se raspravljalo u mjerodavnim tijelima SSRNJ i SSRNH, čak uz spominjanje nepotrebnoga nepovjerenja prema masama, ali i uvlačenja glave među ramena radi izbjegavanja izbora:

„[...] obično se u te delegacije biraju ljudi koji su inače, ono što kažemo, aktivni, koji već imaju svoje zadatke u svojoj organizaciji udruženog rada, u partiji, u Socijalističkom savezu, pa sad, pošto je drug Pero dobar, hajde da ga biramo još onda i u ovu delegaciju." ${ }^{\text {86 }}$

Onodobna literatura nudila je neka rješenja. Neaktivnost i nezainteresiranost građana - koji se „nikad, otkad postoji mjesna zajednica, nisu našli ni na kakvoj zajedničkoj akciji” - ishodište su mogle imati u veličini onih mjesnih zajednica koje su sa svojih 10-20 tisuća stanovnika premašivale okvir zamišljenoga modela i otežavale mu funkcioniranje. ${ }^{87}$ Dakle, mjesne je zajednice trebalo teritorijalno smanjiti, odnosno povećati njihov broj. Trebalo je također angažirati nove aktiviste, posebno mlade (omladinu) i djecu (pionire)

\footnotetext{
81 HR-HDA-1228-SSRNH-RK, kut. 1538, „Aktualna pitanja rada mjesnih zajednica”, 1971.

82 HRŽENJAK, Uloga i zadaci SSRN i SK, 119.

83 HR-HDA-1228-SSRNH-RK, D-Dokumentacija, D-3011, „Stenografski zapisnik sa sjednice Koordinacionog odbora za aktivnost mjesnih zajednica RK SSRNH”, 18. 2. 1975.

84 HR-HDA-1228-SSRNH-RK, D-Dokumentacija, D-3068, „Učešće radnih ljudi i građana u MZ u odlučivanju o politici i sredstvima SIZ-ova: Magnetofonski zapisnik diskusione tribine”, 9. 6. 1975.

85 SMILJANIĆ, „Borci NOR-a u radu i razvoju mjesnih zajednica”, 151-155; VIŠNJIĆ, „Kako ostvariti veći uticaj građana”, 79.

86 HR-HDA-1228-SSRNH-RK, D-Dokumentacija, D-3068, „Učešće radnih ljudi i građana u MZ u odlučivanju o politici i sredstvima SIZ-ova: Magnetofonski zapisnik diskusione tribine”, 9. 6. 1975.

87 HRŽENJAK, Mjesna zajednica, 112.
} 
te suzbijati pojavu pasivnih promatrača i glasačke mašinerije. ${ }^{88}$ Mladi i žene su, osim popravljanja strukture aktivista, mogli pridonijeti i otporu prema primijećenom konzervativizmu i malograđanštini. ${ }^{89}$ Smetnja novom vremenu bili su i „stari revolucionari koji su dali sve od sebe”..$^{90}$ I sam SUBNOR bio je osamdesetih godina svjestan da njegovi članovi u mjesnim zajednicama zauzimaju najodgovornije dužnosti i snažno pridonose poboljšavanju životnih uvjeta, standarda, jedinstva i samoupravljanja. Međutim, iako ponosni na svoju ulogu, borci nisu uživali u tome što nedostaje mlađih nasljednika koji bi od njih preuzimali dužnosti u bazi i osnovnim podružnicama društvenih organizacija te su o tome vrlo kritički govorili:

„Borce 'zabrinjava' što je politička baza u mjesnoj zajednici tijesna i jednostrana, što na raznim skupovima u mjesnoj zajednici osim boraca, jednog broja rezervnih [vojnih] starješina, penzionera i manjeg broja žena-domaćica, nema ni radnika iz neposredne proizvodnje, niti iz društvenih djelatnosti, niti omladine, osim u pojedinačnim slučajevima. Na tim skupovima nema najčešće ni odgovornih ljudi na raznim društvenim funkcijama, kao i većeg broja komunista..."

SUBNOR je upozoravao na potrebu za većom društvenom brigom o mladima, za pomoć u područjima od zapošljavanja do kulture i zabave, posebno u gradovima, gdje je mlade bilo teže okupiti u mjesnoj zajednici. U premošćivanju generacijskoga jaza i nastojanju da socijalizam mladima pokazuje svoje moderno lice društvo je tražilo pravi pristup i nagađalo da su rješenja možda vrlo jednostavna i da ponekad ovise samo o dobrom razgovoru, pravom sadržaju koji nudi „topla i suha prostorija”. ${ }^{92}$ Takvo mjesto ponekad je bila upravo mjesna zajednica kao kvartovsko ili seosko središte zamišljene proširene obitelji.

\section{Aktivisti osobno}

„Primamo ga redovito [...] i za naše aktiviste predstavlja odista veliku pomoć u radu. Tako pratimo iskustva drugih sredina, učimo na konkretnim primjerima i možemo ih uspoređivati - što nam olakšava posao", ustvrdio je 1980. Srećko Krešić, predsjednik VMZ-a Skupštine općine (SO) Metković i

\footnotetext{
HRŽENJAK, Uloga i zadaci SSRN i SK, 120-122.

TOMŠIČ, „Borba za razvoj samoupravljanja”, 94.

HRŽENJAK, Uloga i zadaci SSRN i SK, 124.

„Borci u prvom ešalonu aktivista u mjesnim zajednicama”, $M Z$, br. 10, 1986., 7.

KOPRIVNJAK, „Omladina i Savez omladine u životu mjesne zajednice”, 142.
} 
generalni direktor veletrgovačkoga poduzeća Razvitak..$^{93}$ Riječ je o listu Mjesna zajednica, koji se sa svoje najmanje 24 stranice otisnute u Vjesnikovoj tiskari jednom mjesečno trebao naći u rukama svakoga uzornog aktivista. Podnaslovljen kao „tribina samoupravljanja i društvenog standarda” i u impresumu opisan kao „jedini specijalizirani jugoslavenski list za problematiku samoupravljanja u mjesnim zajednicama", bio je namijenjen mjesnim zajednicama, općinskim skupštinama, organizacijama udruženog rada, samoupravnim interesnim zajednicama, društveno-političkim i društvenim organizacijama te školama. Stručni članci, intervjui, reportaže, analize, dokumenti, posebni prilozi, fotografije, karikature i oglasi bili su tu kao uputa koja olakšava snalaženje i kao potvrda o stanju samoupravljanja u mjestu stanovanja. List je počeo izlaziti još 1959. pod nazivom Porodica $i$ domaćinstvo, koji je potekao od tada osnovanog Saveznog odbora Porodica i domaćinstvo. Stambena zajednica postaje 1960., neposredno po osmišljavanju toga oblika samouprave, a 1963. uvođenjem mjesnih zajednica dobiva svoj konačni naslov. Sintagma iz prvoga naslova zadržana je u nazivu višegodišnjega izdavača - zagrebačke Novinske radne organizacije Porodica i domaćinstvo - no istoimeni je savezni odbor 1971. prerastao u Saveznu konferenciju Mjesna zajednica i porodica, a 1983. u Konferenciju za razvoj mjesnih zajednica Jugoslavije, dok je krovna organizacija ostao SSRNJ sa svojom saveznom i republičkim konferencijama te koordinacijskim odborima za mjesne zajednice. Sedamdesetih je godina savjetom lista predsjedao Juraj Hrženjak, uredništvo su vodili Robert Kramer i Kruna Kancelarić, a u osamdesetima savjet redom preuzimaju Veljko Milatović, Bogdan Trifunović i Dušan Kraljević, a ključne osobe uredništva su Mladen Gerovac, Robert Kramer, Stjepan Leskovec, Vitomir Petrović i Zorica Švegar. Svi oni radili su na jačanju prisutnosti lista među aktivistima i boljem izvještavanju o njihovu radu. Naime, i pored znatne količine sadržaja koja je objavljivana svakoga mjeseca, $\mathrm{u}$ raspravama o razvojnoj orijentaciji lista te $\mathrm{u}$ polaznom dokumentu na kojima su se one temeljile isticalo se da se vijesti o radu aktivista „ne prenose [...] dovoljno brzo i efikasno na sve sredine”. ${ }^{44}$ Otežavalo je to misiju lista koji je svojih oko 20 tisuća pretplatnika izvještavao o „angažiranju dobrovoljnog društvenog rada” te s ukupno 25-30 tisuća otisnutih primjeraka nastojao djelovati kao „instruktažni časopis” i „svakodnevni priručnik" ${ }^{95}$ Pojedini primjerak lista koji se našao na stolu u mjesnoj zajednici vjerojatno je barem prolistalo više čitatelja, no brojke o pretplati i nakladi upu-

\footnotetext{
93 „Predstavljamo predsednike VMZ”, MZ, br. 6, 1980., 37.

94 HR-HDA-1228-SSRNH-RK, D-Dokumentacija, D-6069, „Razvojna orijentacija lista Mjesna zajednica za razdoblje od 1981. do 1985. godine", 1981.

95 HR-HDA-1228-SSRNH-RK, D-Dokumentacija, D-3563, „Magnetofonski zapisnik sa sjednice Odbora za razvoj mjesnih zajednica RK SSRNH”, 17. 5. 1976.
} 
ćuju na to da su prosječno po mjesnoj zajednici kolala samo dva-tri primjerka. Negdje više, negdje nijedan.

Među mnogim rubrikama toga lista bile su dvije s osobnom notom - „Likovi naših aktivista” i „Upoznajemo vas s predsjednicima vijeća mjesnih zajednica" - koje su donosile kratke razgovore s akterima na terenu, najčešće u Bosni i Hercegovini, Hrvatskoj i Srbiji, te opise njihove djelatnosti. Uz prijašnji pokušaj iz 1972., rubrika o aktivistima izlazila je između 1978. i 1990., a ona o predsjednicima vijeća održavala je kontinuitet od 1974. do 1987. godine. Nisu bile zastupljene u svakom broju, no ukupno su uspjele predstaviti osamdesetak pojedinaca, koji su prikazani kao pokretači u svojoj okolini i osobe koje su svojim zalaganjem odskakale od prosjeka. I to je tek mali dio jer djelatnost mnogih drugih ostala je zabilježena u drugim rubrikama. Čak i uz oprez motiviran mogućnošću da su neki nahvaljeni preko mjere i da su neki možda imali lakši pristup novinskim stranicama - dok su drugi, više ili manje vrijedni, bili zanemareni - stranice lista donose bogat katalog lokalnih društveno-političkih radnika i aktivista te izvor iz kojega se iščitavaju njihove pobude, zadovoljstva i kritike. Profili su po mnogočemu slični, no među predsjednicima vijeća mjesnih zajednica više je onih koji su u naponu snage i nastoje oblikovati svoju karijeru, pa i onu političku. S druge strane profili aktivista pripadali su starijoj ili mlađoj generaciji, dakle onima čija je radna dob već završila ili onima kojima je karijera tek slijedila, ako su uopće imali takvih aspiracija.

„To su novi učesnici naše revolucije - graditelji novih samoupravnih odnosa u mjesnim zajednicama i komuni. Gotovo da i nema mjesne zajednice 'koja dobro radi' bez takvih ljudi: tihih, svakodnevnih, običnih, ali velikih po zalaganju i oduševljenju koje prenose na svoju okolinu. Zato pozivamo mjesne zajednice da nam pišu o istaknutim aktivistima i društveno-političkim radnicima u svojim sredinama - o ljudima koji često puta i ne znaju za odmor - o onim entuzijastima koji su uvijek u prvim redovima svake akcije." 96

I mjesne zajednice doista jesu pisale i pozivale novinare da ih posjete, a njihovi su reci punili dvije spomenute rubrike. Tako su se iza promicanoga idealnog tipa aktivista na stranicama lista počele javljati i profilirati stvarne osobe sa svojim iskustvom i osobinama, već nagrađivane ili dotad neprepoznate. Raspon je bio širok, od onih malih karika iz seoskih mjesnih zajednica do lokalnih političara iz općinskih tijela, posebno iz vijeća mjesnih zajednica. U takav su se raspon sa svojim osobinama, koje su mogle biti primjer ostalima, uklapali Andrija Ćuk, predsjednik VMZ-a u Općini Donja Stubica i direktor OOUR-a Astra - ugostiteljstvo, te Miho Orlić, tajnik seoske MZ Juršići u Općini Pula: 
„Ćuk voli rad i red, voli novo, akciju i aktivnost. Promišljeno i s dugogodišnjim iskustvom privrednog, turističkog i društvenog radnika, prima prijedloge, mišljenja, razmišlja, razlaže i odabire najbolje. Nije prijatelj mnogo riječi, voli akciju." 97

„Zatekli smo ga znojnog, s čekićem u ruci, 15 minuta prije početka fešte. Čovjek koji nema mira. Okretan, živahan, poslovno rastrzan. Za kratko vrijeme koje smo proveli u Juršićima - za sve nam je trebao Miho... [...] Miho zna sve o svakoj akciji. [...] Od papira - do posljednjeg čavla." ${ }^{\prime 98}$

Sadržaj koji povezuje profile aktivista mogao bi se svesti na tri osnovne značajke: visoka razina radnoga elana, slobodno vrijeme koje se želi uložiti u opće dobro te jasni izvori motivacije za djelatnost u susjedstvu. To su niti koje se provlače kroz sva predstavljanja aktivista. Pritom je dobra motivacija jačala radnu energiju, no posljedica je bilo skraćivanje doista slobodnoga vremena, onoga koje su aktivisti mogli zadržati samo za sebe. Ne manje važan čimbenik i dobro gorivo u tom suodnosu bilo je zadovoljstvo nakon kvalitetno obavljena posla i ohrabrujuća povratna informacija koja je stizala od građana. Povezanost zadovoljstva i motivacije nije bila rijetka u novinskim člancima o aktivistima, a isticali su ju i mlađi i umirovljeni nastavnici koji su svoje iskustvo crpili iz rada s učenicima. Ramiz Nizić iz MZ Binježevo u Općini Hadžići zaključio je da mu rad u mjesnoj zajednici pruža zadovoljstvo kao i nekad rad na radnome mjestu te da se „osjeća srećnim kad riješi neko pitanje za ljude”. ${ }^{99}$ Vaso Simikić, predsjednik Mirovnoga vijeća MZ Ražljevo kraj Brčkog, bio je sretan kad je pridonosio sreći svojih sumještana: „To osećanje me podstiče i motiviše da ne sustanem iako sam već u godinama." ${ }^{00}$ Uspjesi su bili poticaj i za Mitra Zimonjića iz MZ Grčica u Općini Brčko, no bio je tu i osjećaj obveze: „To što ja radim ne radim zbog priznanja i hvala. To mi je obaveza kao građanina i komuniste."101 Slično je razmišljao 54-godišnji prosvjetni radnik Pavel Roharik iz MZ Padina u Općini Kovačica, koji je, svjestan da u mjesnoj zajednici građani ostvaruju svoje potrebe, prava i obveze, angažman osjećao kao svoju dužnost. ${ }^{102}$ Sjećajući se ratnih strahota, „ravnodušna prema nastojanjima društva da gradi bolje sutra” nije mogla biti učiteljica Milica Stankov iz MZ Aleksa Šantić i istoimenoga sela kraj Sombora. ${ }^{103}$ Jednako tako Jelena Bajić, aktivistica u sarajevskoj MZ Baščaršija i zaposlenica Socijalističkoga saveza radnog naroda Bosne i Hercegovine, nije

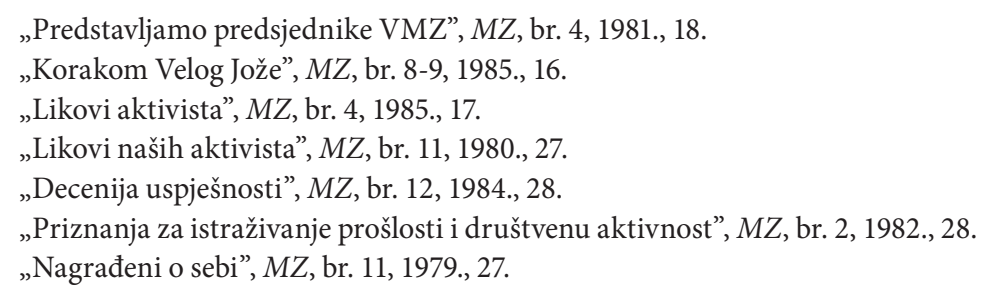


mogla bez svoje mjesne zajednice, s kojom se, slikovito je izjavila, „rodila”, pa ju „problemi sa kojima MZ živi uvijek mobilišu na nove akcije”. ${ }^{104}$ Mnogi su se na sličan način zapravo poistovjetili sa sredinom u kojoj su djelovali, pa je Šime Barićev, zaljubljenik u svoj posao koji je u svakom novoizgrađenom riječkom objektu vidio još jednu radnu pobjedu, mogao reći „imam osjećaj da je u nju ugrađen dio mene”, a znalac splitskoga područja Ante Mužić s užitkom ustvrditi „sada su sve splitske mjesne zajednice 'moje”". ${ }^{105}$ „Njegov drugi dom” mjesna je zajednica bila i Mihajlu Stojkoviću, nagrađenom sekretaru VMZ-a SO Pančevo. ${ }^{106}$ Obrnut je bio slučaj Vlastimira Kneževića iz Nove Pazove - čovjeka „koji se najčešće spominje i najviše hvali [...] istovremeno i najviše grdi i kudi” - kojemu je dom postao dodatni ured mjesne zajednice i ondje je primao mještane koji su dolazili sa svojim zahtjevima i prijetnjama. ${ }^{107}$

Želja za boljom životnom sredinom i teškoće u zadovoljavanju zajedničkih javnih potreba mogle su biti ključna motivacija aktivistima, koji su pritom mogli pokazivati mnogo entuzijazma, ali i prepoznavati unutarnje slabosti. U godini kad su mjesne zajednice postale ustavna obveza, iz krugova u kojima se raspravljalo o njihovoj organizaciji i učinkovitosti dolazila su tako stajališta puna optimizma, ali i ona koja su upozoravala na moguće zamke. ${ }^{108}$ Ivan Šafran iz zagrebačke Općine Centar smatrao je da u sustav ulazi nova „životna energija”, da će se ponovno dobro raditi te da će građani radi ostvarivanja zajedničkih potreba „dati svoje slobodno vrijeme, pa ako zatreba i sredstva”. $S$ druge strane Ante Balenović iz zagrebačke Općine Dubrava isticao je da volonteri, koji imaju svoje radno mjesto, u mjesnoj zajednici postaju pasivni jer „ako radnik predlaže, diskutira, daje zdrave prijedloge i zalaže se za određena pitanja a godinama ne vidi ploda, povlači se i više nije zainteresiran da sudjeluje u odlučivanju”. Poznate su bile teme i aktivnosti za koje je bilo lakše zainteresirati građane. „Najbrže se ljudi opredijele za one akcije komunalnog karaktera kojima se rješavaju problemi što ih najviše tište i zaokupljaju. [...] Upravo u takvim akcijama do punog izražaja dolazi jedinstvo i solidarnost građana”, tvrdio je Juraj Katovčić, stomatolog i krajem sedamdesetih predsjednik VMZ-a SO Jastrebarsko. ${ }^{109}$ Neovisno o stranputicama pasivizacije i sa sviješću o tome da radno mjesto oduzima tek trećinu uobičajenoga dnevnog vremena, kod Đure Rebića, predsjednika Vijeća udruženog rada (VUR) SO Karlovac i inženjera u Jugoturbini, postojala je želja „da svaki radnik bude aktivni činilac zbivanja u svojoj mjesnoj zajednici gdje provodi dvije trećine

104 „Likovi aktivista”, $M Z$, br. 3, 1987., 18

105 „Likovi naših aktivista”, $M Z$, br. 5, 1978., 11; „Likovi naših aktivista”, MZ, br. 6, 1978., 2.

106 „Predstavljamo vam predsjednike vijeća mjesnih zajednica”, $M Z$, br. 3, 1975., 18-19.

107 „Likovi istaknutih aktivista”, $M Z$, br. 3, 1972., 20.

108 „Vi ste vlast - riješite problem”, $M Z$, br. 11, 1974., 16-18.

109 „Predstavljamo predsjednike VMZ”, MZ, br. 2, 1979., 8. 
života”. ${ }^{110}$ Međutim, primjećivalo se na terenu da sastanci „u zamornoj beskonačnosti vode do nezainteresiranosti” te da nakon dobrih zaključaka nema njihove primjene, što dovodi do opadanja aktivnosti. ${ }^{111}$ Sastanci koji se „pretvaraju u veliko gubljenje vremena” nisu bili nepoznanica ni u znanstvenoj literaturi kasnoga socijalizma. ${ }^{112}$

Iz tih i mnogih sličnih stajališta proizlazi da se oslanjanje na aktiviste i volontere u mjesnoj zajednici kretalo u ne previše široku prostoru u kojem je među zainteresiranima za mjesnu zajednicu trebalo zadržati radno aktivne i zaposlene građane, održati njihov volonterski status te ne dopustiti da njihovi dobri prijedlozi i inicijative ostanu neprihvaćeni i neostvareni. Osjećaj ulaska u slijepu ulicu mnoge je udaljavao od društvenoga angažmana. Čini se da je u takvim uvjetima klackalica na kojoj su snage odmjeravali aktivnost i pasivnost, volonterstvo i profesionalnost, entuzijazam i razočaranje, uspjesi i neuspjesi ili pak radno i slobodno vrijeme morala biti prilično složen mehanizam.

Spremnost na ulaganje vlastitoga slobodnog vremena u boljitak svoje okoline bila je zajednička svim dobrim aktivistima. Ipak, često se radilo o mlađim umirovljenicima koji su u želji da i dalje budu aktivni svoj prostor pronalazili u mjesnoj zajednici ili su u njoj u kasnijoj životnoj dobi zadržali utjecajno mjesto kakvo su prije imali. Najvažnije je ipak bilo da takav angažman nisu osjećali kao teret, nego su njegove rezultate smatrali svojom nagradom. Stjepan Novosel iz ozaljske MZ Hrašće, ujedno tajnik općinskoga SUBNOR-a, bio je krajem sedamdesetih već deset godina u mirovini, ali lokalno vrlo angažiran u kraju u kojem su vodu i struju dobili upravo zahvaljujući samodoprinosu i dobrovoljnom radu. ${ }^{113}$ Puna radnoga elana bila je Mica Makar, predsjednica Koordinacijskoga odbora za mjesne zajednice pri Općinskoj konferenciji SSRN-a u Bjelovaru te članica odbora pri Republičkoj konferenciji SSRNH i Saboru Socijalističke Republike Hrvatske, koja je „sav svoj rad i slobodno vrijeme ulagala [...] u obilazak sela, u tumačenje uloge MZ”, ističući da ju veseli rad s ljudima i rješavanje zajedničkih problema. ${ }^{114}$ Dobro planiranje vremena kao ključ društvene angažiranosti spominjalo se uz ime Radenka Jovanovića, 56-godišnjega poljoprivrednika, predsjednika Savjeta MZ Jabučje kraj Kragujevca i bivšega delegata u općinskom VUR-u. ${ }^{115}$ Umirovljeni kapetan korvete Milan Antunac, nekadašnji skojevac i borac u 14. dalmatinskoj brigadi, iz MZ Veli Iž u zadarskom arhipelagu u šali je isticao da „radi za trojicu” te da obavlja

\footnotetext{
110 „Interesi MZ su interesi radnika”, MZ, br. 11, 1978., 21.

111 „Efikasniji oblici i metode rada SSRN u Puli”, MZ, br. 4, 1987., 9.

112 HORVAT, ABC jugoslavenskog socijalizma, 24.

113 „Likovi naših aktivista”, $M Z$, br. 11, 1978., 23.

114 „Likovi naših aktivista”, $M Z$, br. 5, 1978., 11.

115 „Likovi aktivista”, $M Z$, br. 6, 1984., 19.
} 
poslove, poput knjigovodstva, s kojima se nikad prije nije susretao: „Radim sve što treba [...] Kad se voli mjesna zajednica - sve se nauči raditi!"116 Vujadin Andrić iz MZ Pučile kraj Bijeljine, iako u dobi od 63 godine, bio je „uvijek u pokretu” te još od mladosti sudjelovao i na sastancima i u radnim akcijama, a ni kao umirovljenik nije posustajao: „... imam više slobodnog vremena od drugih, a nije mi, vala, ni teško." ${ }^{117}$ Bio radni dan ili nedjelja, svejedno je bilo Vladi Vidoviću iz MZ Kočićevo kraj Bosanske Gradiške, nekadašnjem poslovođi prodavaonice, osnivaču nogometnoga kluba i organizatoru radnih brigada, koji je teren obilazio svojim automobilom ne tražeći naknadu: „On radi kao iz inata. Ne čuje hvale, niti je traži."118

Po pisanju lista, mnogi stariji aktivisti u svojoj su sredini doživljavani kao nezamjenjivi. Ramiz Drljević iz MZ Kopači u Općini Goražde bio je društveno-politički aktivan još od 1946., a ni četrdesetak godina poslije kao umirovljenom željezničaru nije mu nedostajalo „elana i volje”. ${ }^{119}$ Dugogodišnji nagrađivani društveni radnik i ratni invalid Luka Stamenković u jednoj niškoj mjesnoj zajednici nije posustajao ni sa 62 godine i bio je spreman raditi dokle god bude bio sposoban i tražen: „Ništa ne prećutim, a opet me, eto, traže, računaju na mene." ${ }^{20}$ Od sastanaka i obveza u svojoj MZ Prva Kutina kraj Niša nije bježala poljoprivrednica Anka Petrović, koja je ondje bila poznata „po jasnim i konkretnim diskusijama” i općenito nezamjenjiva, iako i sama pomalo nezadovoljna što su se mlađe i obrazovanije žene i dalje oslanjale na nju. Sličan je problem imao 70-godišnji Milorad Dragojlović iz MZ Skela kraj Obrenovca, umirovljenik s bogatim iskustvom u mjesnoj zajednici i općini, koji se žalio na godine i nemogućnost povlačenja, otkrivajući pritom i težinu djelovanja među ljudima na terenu.

„Pa zar ostavi dan ko dukat vredan da sastančiš, znaju često da mi kažu komšije. A ja na to gledam ovako: važno je da se dogovorimo, da znamo što hoćemo, pa kad svako uradi ono za što je zadužen, onda će nam napredovati i poljoprivreda i čitavo selo. [...] Sada me malo i godine omele, ali kad sam bila mlađa kao da nisam znala za umor. Uveče se vraćam s njive, ostavljam motiku i odlazim na zbor građana ili na sastanak aktiva žena, ili na neki društveni zadatak."121

„Davao sam ostavku nekoliko puta. Star sam, brate, da prisustvujem maratonskim sednicama, a kamo li da usaglašavam mišljenja 'stotinu ljudi i stotinu

\footnotetext{
116 „Likovi naših aktivista”, $M Z$, br. 5, 1978., 11.

117 „Likovi aktivista”, $M Z$, br. 4, 1985., 17.

118 „Likovi naših aktivista”, MZ, br. 11, 1978., 23.

119 „Likovi aktivista”, MZ, br. 7, 1984., 20.

120 Isto.

121 „Likovi aktivista”, $M Z$, br. 6, 1984., 19.
} 
ćudi', da predsedavam i ubeđujem one od kojih su i očevi digli ruke, o prednosti ulaganja i rada za opšte dobro mesne zajednice."122

Sigurno su godine života i rada ostavljale traga na starijim aktivistima, no nespremnost većega broja mladih na angažman i preuzimanje poslova stavljali su dokazane starije kadrove u položaj odgađanja stvarnoga umirovljenja i dovodili do njihove nezamjenjivosti. Ismet Gračić iz banjalučke MZ Nova Varoš u mirovini je bio od 1952. i zbog zdravstvenoga se stanja 1990. morao povući, no desetljećima je bio „vrsni aktivist”, posebno u mjesnoj organizaciji Crvenoga križa, gdje je članstvo tražilo da ne odstupa „jer je to bila najveća garancija da će mjesna organizacija uspjeti u svom radu" ${ }^{123}$ I pored svih rečenica o zajedničkom djelovanju u međugeneracijskoj povezanosti, u iskazima zabilježenim u tisku može se primijetiti procijep između udaljenih naraštaja, kao i između poratnoga vremena i kasnoga socijalizma. Nakon 35 godina društvenoga rada u mirovinu je sredinom sedamdesetih otišla dinamična Zena Kalogjera te je u želji da i dalje bude aktivna 1978. djelovala kao predsjednica Savjeta MZ Gornji grad u Zagrebu, ali i u tijelima na općinskoj i republičkoj razini. Najviše joj je smetalo „što se traži mnogo administriranja”, koje je, smatrala je, uništavalo pravu samoupravnu ulogu mjesne zajednice.

„Ali, ipak, nekada je bilo lakše - ne zato što smo bili mlađi, već zato što se tada radilo na obnovi, s više elana i oduševljenja zasnovanog na zajedničkom interesu, na jedinstvenoj želji." 124

Na svoj se način poratnoga vremena tada sjećao 82-godišnji zidar Veljko Damnjanović Brka iz Kovačevca, čitateljima predstavljen kao najjači mještanin i sudionik svih građevinskih radova: nije zaboravio kako se gradilo i sredstvima mještana i dobrovoljnim radom te najčešće bez projekta. ${ }^{125}$ Uvjerena u snagu herojskih godina i svoje generacije bila je još jedna aktivistica koju su novinari pitali za usporedbu s prošlosti. „Smatram da sa malo više volje mogu nastaviti rad nas revolucionara”, zaključila je osamdesetih godina o mladima Razija Dujković, umirovljena nastavnica i direktorica osnovne škole, predstavljena kao osoba puna optimizma i energije, dobitnica mnogih nagrada i predsjednica Općinske konferencije SUBNOR-a u Novom Sarajevu, ujedno poklonica poratnoga kulta rada.

\footnotetext{
122 „Osam plodnih godina”, MZ, br. 3, 1982., 29.

123 „Likovi aktivista”, $M Z$, br. 2, 1990., 21.

124 „Likovi naših aktivista”, $M Z$, br. 6, 1978., 29.

125 „Likovi naših aktivista”, $M Z$, br. 11, 1978., 23.
} 
„Mislim da smo mi posebna generacija - SKOJEVSKA. Naučili smo na stalan rad, odgovornost. Sve zadatke izvršavali smo na vrijeme. Ja, recimo, nisam nikada zakasnila na sastanak, a kamoli na posao. A kroz rad sve je ljepše..."126

Ipak, mnogi su aktivisti radili s mladima nastojeći im prenijeti metode djelovanja i društvene vrijednosti. Okupljali su ih u mjesnoj zajednici, osiguravali prostor za rad i zabavu, organizirali tečajeve i seminare političkoga sadržaja, nudili kulturne i sportske programe, osnivali klubove, turnire i natjecanja. U tom smjeru djelovali su, primjerice, Dževad Mujkanović iz Fojnice i Jan Njemoga iz Kovačice. ${ }^{127}$ Svoje je iskustvo mlađima diljem Općine Strumica, „ne žaleći ni truda ni vremena”, prenosio Aleksa Mitev. ${ }^{128}$ U selu Šabići u MZ Badić kraj Bosanske Krupe pokretač mladih bila je upravo jedna od njih: Mina Šabić, koja je krajem 1981. pohađala četvrti razred gimnazije. ${ }^{129} \mathrm{Uz}$ njezino vodstvo, mladi su podizali omladinski dom, gradili i održavali cestu prema općinskom središtu, pomagali pri sjetvi i kupovali glazbene instrumente.

\section{Zaključak}

Među tisućama građana koji su kao volonteri ili profesionalizirani službenici svoje slobodno i radno vrijeme ulagali u mjesne zajednice bili su brojni aktivisti, pokretači i organizatori raznih akcija, predsjednici savjeta mjesnih zajednica, tajnici, predsjednici mirovnih vijeća i savjeta potrošača, čelnici podružnica Saveza komunista, SSRN-a i drugih organizacija, delegati u drugim karikama delegatskoga sustava, društvenoga samoupravljanja i udruženoga rada. Raspon osobnih profila bio je vrlo širok - „od poljoprivrednika, inženjera, oficira JNA do penzionera". ${ }^{130} \mathrm{Na}$ temelju obrađenih osamdesetak profila aktivista moguće je izdvojiti nekoliko karakterističnih tipova: prvi su bili umirovljeni časnici koji su htjeli pridonositi društvu i njegovoj ideološkoj ispravnosti, ali i u mirovini upravljati kolektivom koji im je donekle podređen; drugi su bili umirovljene društvene ili prosvjetne radnice i radnici koji su željeli biti okruženi ljudima, poboljšavati međusobne odnose, kvalitetu života i društveni standard; treći su tip činili poljoprivrednici, muškarci i žene srednje i starije generacije koji su bili cijenjeni pokretači lokalne sredine, prirodni vođe s iskustvom još iz godina ranoga socijalizma te kao takvi često nezamjenjivi; četvrti su najčešće bili muškarci zaposleni u neindustrijskom sektoru koji su imali energije i vremena za društveni angažman te pokazivali zanimanje za politiku; peti su tip bili omla-

\footnotetext{
126 „Likovi aktivista”, $M Z$, br. 6, 1984., 19.

127 „Likovi aktivista”, $M Z$, br. 1, 1980., 27; „Doprinosi Jana Njemoge”, $M Z$, br. 10, 1983., 29.

128 „Likovi aktivista”, $M Z$, br. 7, 1984., 20.

129 „Likovi aktivista”, $M Z$, br. 12, 1981., 25.

130 „Na dnevnom redu - životni problemi”, $M Z$, br. 11, 1978., 21.
} 
dinke i omladinci kao mlade snage u usponu koje su tek izgrađivale svoje mjesto u društvu, pa su ulažući u zajednicu pomagali i svojoj budućnosti. Ponekad su se ti tipovi dobro dopunjavali, ponekad su bili smetnja jedni drugima zbog različitih generacijskih i klasnih interesa iz kojih su proizlazili različiti pristupi prioritetima, planovima i načinu rješavanja problema.

„Znaju oni, brate, i da rade i da organizuju posao i hoće. Ja sam penzioner i stariji sam čovjek, ali moram priznati da baš ti stariji, kojih ima dosta u većini mjesnih zajednica, puno smetaju. Oni treba da ponude iskustvo i da pomognu, ali treba da poslušaju i mlađe. Ako hoćete zabilježite, ako nećete ne morate, ali mislim da bi svaka mjesna zajednica mnogo efikasnije izvršavala svoju ulogu kada bi više građana bilo angažovanih u njenom radu. Sav teret se obično svali na grupu ljudi koji hoće raditi. Tako je to svugdje pa i kod nas." ${ }^{\text {"31 }}$

Složenije je bilo raditi onima u seoskim mjesnim zajednicama koje su obuhvaćale više udaljenih naselja, no možda i otuđeni teren suvremene gradske četvrti s velikim stambenim zgradama nije bio bez svojih specifičnosti i otegotnih okolnosti. Mnogi su se kao aktivisti ili lokalni političari dokazali te postali primjer dobre prakse i dobitnici nagrada. S druge strane mnogi se u svojim ulogama - koje su preuzeli odgovorno i s odobravanjem okoline ili uz određenu mjeru društvene obveze ili čak pritiska u nedostatku drugih kandidata - nisu najbolje snalazili. Nekima je nedostajalo vremena, nekima obrazovanja, nekima suradnika i agilnih sugrađana, nekima žara koji bi mjesnoj zajednici dao odgovarajući sadržaj.

Svi zajedno našli su se u prostoru koji su početkom sedamdesetih godina ocrtavala očekivanja, poput onih slovenske političarke Vide Tomšič, da će rad u mjesnoj zajednici biti „još mnogo raznovrsniji i bogatiji nego što o njemu dosad znamo", a sredinom osamdesetih pozivanje da rad u mjesnoj zajednici treba više cijeniti. ${ }^{132} \mathrm{U}$ međuvremenu se odvijalo složeno usklađivanje odnosa, obveza i očekivanja. Oni od kojih se pritom očekivalo da uvijek nastupaju kao samoupravljači mogli su čak nezainteresirano reći: „Vi ste 'vlast', riješite problem.”"133 Takva pasivnost dijela građana bila je trajni problem i pokazivala je da - nasuprot mogućem angažmanu na radnome mjestu - u svoje slobodno vrijeme i na mjestu stanovanja nisu bili spremni koristiti ponuđene poluge društvenoga samoupravljanja. Mehanizam socijalističke izravne demokracije nailazio je na prepreke, ali sigurno je da su mnogi aktivisti u prostoru mjesne zajednice pronašli svoje mjesto, pokazivali inicijativu i nastojali pokrenuti svoje susjede koje je svakodnevni život odvlačio od želje da uopće pokušaju biti samoupravljači.

\footnotetext{
131 „Decenija uspješnosti”, $M Z$, br. 12, 1984., 28.

132 TOMŠIČ, „Borba za razvoj samoupravljanja”, 97; HRŽENJAK, Uloga i zadaci SSRN i SK, 140. 133 „Vi ste vlast - riješite problem”, $M Z$, br. 11, 1974., 16-18 (Vera Smiljanić, predsjednica delegacije MZ Sopot, Općina Novi Zagreb).
} 


\section{Izvori}

ĐURIĆ, Đorđe; HRŽENJAK, Juraj; KIRINČIĆ, Miroslav; PETROVIĆ, Goranka. Zakon o mjesnim zajednicama SR Hrvatske. Priručnik za primjenu zakona i ostvarivanje ustavne uloge mjesnih zajednica. Zagreb: NRO Porodica i domaćinstvo, 1984.

HR-HDA-1228-SSRNH-RK: Hrvatska, Hrvatski državni arhiv, Zagreb, fond 1228, Socijalistički savez radnog naroda Hrvatske. Republička konferencija.

Mjesna zajednica (Beograd; Zagreb), 1972-1990.

Narodne novine (Zagreb), 19 (1983).

Program Saveza komunista Jugoslavije. Prihvaćen na Sedmom kongresu Saveza komunista Jugoslavije (22-26. travnja 1958. u Ljubljani). Zagreb: Stvarnost, 1965.

Ustav Socijalističke Federativne Republike Jugoslavije. Ustav Socijalističke Republike Hrvatske. Zagreb: Narodne novine, 1986.

\section{Literatura}

DUDA, Igor. „Consumers and Self-Managers: Consumer Protection and its Challenges during the Yugoslav Economic Crisis of the 1980s". Acta Histriae 27 (2019), br. 1: 143-162.

DUDA, Igor. „Consumers as the Vehicles of Socialism. Consumer Protection in the System of Yugoslav Self-Management and Associated Labour". Südost-Forschungen 76 (2017): 1-23.

DUDA, Igor. „Potrošači kao nositelji socijalizma. Zaštita potrošača u sustavu društvenoga samoupravljanja i udruženoga rada”. U: Stvaranje socijalističkoga čovjeka. Hrvatsko društvo i ideologija jugoslavenskoga socijalizma, ur. Igor Duda. Zagreb; Pula: Srednja Europa; Sveučilište Jurja Dobrile, 2017, 245-272.

ĐORĐEVIĆ, Jovan. „Neka pitanja ostvarivanja i razvitka socijalističke demokratije”. Politička misao 2 (1964): 153-182.

HORVAT, Branko. ABC jugoslavenskog socijalizma. Zagreb: Globus, 1989.

HRŽENJAK, Juraj. Mjesna zajednica. Osnove sistema neposredne socijalističke demokracije na mjestu stanovanja. Zagreb: Globus, 1974.

HRŽENJAK, Juraj. Uloga i zadaci SSRN i SK u mjesnoj zajednici. Priručnik za društveno-političke aktiviste u mjesnoj zajednici. Zagreb: NNRO Porodica i domaćinstvo, 1986.

KARDELJ, Edvard. Mesna zajednica u sistemu socijalističkog samoupravljanja. Zagreb: NRO Porodica i domaćinstvo, 1985.

KARDELJ, Edvard. Pravci razvoja političkog sistema socijalističkog samoupravljanja. Beograd: Izdavački centar Komunist, 1978. 
KOPRIĆ, Ivan. „Razvitak formiranja društveno-političkih zajednica u SFRJ”. Pravnik 35 (1987), br. 1: 19-23.

KOPRIVNJAK, Vjekoslav. „Omladina i Savez omladine u životu mjesne zajednice”. U: Društveno-političke organizacije u mesnoj zajednici, ur. Robert Kramer. Zagreb; Beograd: NP Porodica i domaćinstvo, 1973, 137-150.

KRAMER, Robert, ur. Društveno-političke organizacije u mesnoj zajednici. Zagreb; Beograd: NP Porodica i domaćinstvo, 1973.

PUSIĆ, Eugen. Komuna i općina. Zagreb: Informator, 1981.

PUSIĆ, Eugen. Upravni sistemi, knj. 2. Zagreb: Grafički zavod Hrvatske; Pravni fakultet u Zagrebu, Centar za stručno usavršavanje i suradnju s udruženim radom, 1985.

SMILJANIĆ, Nikola. „Borci NOR-a u radu i razvoju mjesnih zajednica”. U: Društveno-političke organizacije u mesnoj zajednici, ur. Robert Kramer. Zagreb; Beograd: NP Porodica i domaćinstvo, 1973, 151-160.

TOMAC, Zdravko. Mjesna zajednica u teoriji i praksi. Zagreb: Izdavačko i propagandno poduzeće Zagreb, 1977.

TOMAC, Zdravko. „Općina kao samoupravna socijalistička zajednica”. Politička misao 16 (1979), br. 3: 448-460.

TOMŠIČ, Vida. „Borba za razvoj samoupravljanja u mesnoj zajednici - deo revolucionarne delatnosti komunista”. U: Društveno-političke organizacije u mesnoj zajednici, ur. Robert Kramer. Zagreb; Beograd: NP Porodica i domaćinstvo, 1973, 85-98.

TUBIĆ, Risto. Enciklopedijski rječnik marksističkih pojmova. Sarajevo: Veselin Masleša, 1974.

VIŠNJIĆ, Miodrag. „Kako ostvariti veći uticaj građana u mesnim organizacijama na ukupnu politiku Socijalističkog saveza”. U: Društveno-političke organizacije u mesnoj zajednici, ur. Robert Kramer. Zagreb; Beograd: NP Porodica i domaćinstvo, 1973, 73-84. 


\section{SUMMARY}

\section{'I'm Doing all that's Needed.' Activists in Local Communities in Yugoslavia during the 1970s and 1980s}

After the experience with people's committees, small municipalities, and residential communities, socialist Yugoslavia began introducing local communities as self-governing units and communities of citizens within the new, larger municipalities. They were a way of strengthening social self-management and socialist direct democracy and, according to Marxist theory, envisioned as part of the withering away of the state, and therefore part of the process of de-bureaucratisation and humanisation of social relations. The foundations of the new socio-political organisation were set down by the 1963 Constitution, but it was only the 1974 Constitution that established local communities as one of the core parts of the socio-political system and a compulsory form of citizens' self-government organisation. Envisioned as something akin to extended families, they were greatly dependent on initiatives from below, on the energy, enthusiasm, and free time of interested citizens. Therefore, this paper attempts to answer the following questions: how was the concept of local communities envisioned; did citizens' interest reach the expected level, and who were the activists among them; what prompted their enthusiasm, and how did they understand their activities? Based on our analysis, we establish the characteristic types of activists determined by generational, class, and interest relations. In defining the theoretical and practical aspects of social self-government in local communities, the paper refers to the Programme of the League of Communists of Yugoslavia, constitutional and legal provisions, and the theoretical tenets of the actors of that period. Our approach also considers the then and current papers from the field of administrative sciences. The everyday and practical activities in local communities are analysed based on the writings published in Mjesna zajednica (Local Community), the specialised monthly of the Conference for the Development of Local Communities, which acted as part of the Socialist Alliance of the Working People of Yugoslavia, as well as archival data from the fond of the Republican Conference of the Socialist Alliance of the Working People of Croatia.

Key words: local community; social self-management; socialist democracy; participation; activism; Yugoslavia 